\title{
An Investigation into Student Engagement in Higher Education Classrooms
}

\author{
Paula Witkowski, PhD \\ Associate Professor, School of Education \\ Webster University \\ Thomas Cornell, PhD \\ Associate Professor, School of Education \\ Webster University
}

\begin{abstract}
This article reports on a one-year research project that used peer coaching and collaboration between two reading professors to study the effects of collaborative classroom activities on student engagement. In order to address professors' concerns about student participation, two undergraduate reading-methods classes were revised through the inclusion of more collaborative learning activities.

Classroom observations were conducted to take notes on both pedagogical methods and student response to these methods. Students were also asked to self-assess their engagement in behavioral, cognitive, and affective domains. The results of this research were then used to revise pedagogical techniques in these and other classes.
\end{abstract}

"Are there any questions?" "What do you think about this?" These are phrases commonly heard in many college classrooms-unfortunately, they are often met with silence. Student passivity in learning situations is a problem that plagues university professors and causes them to search for better ways to help students become more active participants and learners. Suggestions for ways to encourage this active participation are plentiful, but which are most productive? This study examined student engagement in two undergraduate reading methods courses. The focus was on the use of "teaching techniques that allow for all students to demonstrate, at the same time, active participation and cognitive engagement in the topic being studied" (Himmele \& Himmele, 2011, p. 7). We began with the following question: What are effective methods for enhancing student engagement in the higher education classroom?

\section{Review}

Student engagement and learning are issues that have become nationally important in the $21^{\text {st }}$ Century. Wieman and Perkins (2005) examined the relationship between traditional instruction and student learning and suggested better approaches for teaching physics such as avoiding cognitive overload, using technology, and engaging students in well-designed computer simulations. Petress (2006) pointed out that learning was enhanced when students were active rather than passive. Beran and Violato (2009), David (2004), Freeman, Anderman, and Jensen (2007), Rocca (2008/2009), and Chiu (2009) all examined factors such as classroom atmosphere and faculty-student interactions that

What are effective methods for enhancing student engagement in the higher education classroom? influenced student engagement. In November 2011, both Inside Higher Ed and The Chronicle of Higher Education presented articles dealing with the importance of student engagement. In response to these concerns as well as experiential concerns on the same topic, educators in higher education settings began to more closely investigate specific strategies that would motivate students to become better learners. Goldberg and Ingram (2011) investigated active learning techniques in lower-division biology classes and found that student engagement was improved when mini-lectures were paired with active-learning activities such as development of concept maps, problem-solving exercises, and a 
categorization grid. Auman (2011) designed a simulation-based pedagogy for her Educational Psychology class and found that game simulations resulted in increased engagement on the part of both students and herself. AlKandari's (2012) investigation into student perceptions about classroom discussions found that students positively acknowledged that discussions, debates, group work, and presentations were designed to enhance their learning and communication and resulted in increased engagement and motivation to learn.

In their book, Himmele and Himmele (2011) presented 37 'Classroom Ready Total Participation Techniques' (TPTs) designed to engage and motivate learners in $\mathrm{K}-12$ settings. These techniques were also used in their own university classrooms at Millersville University. Their self-stated goal was to avoid the 'stand and deliver' approach commonly used in college classrooms, which would result in turning students into "listening objects" (Freire, 2000, p.7). Instead, they promoted the use of techniques that engaged students at higher levels of thinking. This philosophy was embedded into our own study as several TPTs were introduced throughout each semester.

\section{Method}

\section{Participants}

The purpose of this study was to determine which teaching techniques best-enhanced student participation and engagement in reading methods classrooms. This mixed-methods study included both quantitative and qualitative analysis of data collected over the course of two semesters during the 2012-2013 school year. The sample of convenience was comprised of 55 students who were enrolled in two reading methods courses required for elementary teacher certification.

Informed subjects gave their consent to use solicited feedback and observation data related to their participation in class. At the end of each semester students were asked to complete a survey concerning their opinions related to collaborative activities.

\section{Research Design}

The process of peer coaching was used as a means of providing support and feedback to the researchers involved (Pellicer \& Anderson, 1995). Researchers would visit each other's classrooms and take notes and then meet weekly to inform one another about observed student engagement levels during class activities. This analysis was based on the use of Himmele and Himmele's (2011) TPT Cognitive Engagement Model and Quadrant Analysis (Figure 1).

To control for bias and cross-validate results, a graduate research assistant was hired and trained to observe both classes and to take detailed notes based on the TPT Cognitive Engagement Model and Quadrant Analysis. These notes included the amount of time

\section{TPT Cognitive Engagement Model and Quadrant Analysis}

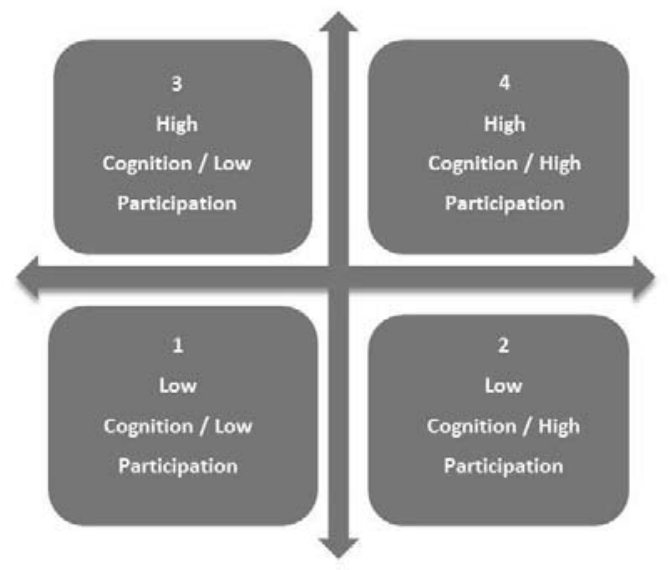

Figure 1. TPT Cognitive Engagement Model 
devoted in class to instructional strategies as well as analysis to determine levels of cognition and participation. The independent observer's notes were combined with the researchers' data for analysis of the percentage of time devoted to each quadrant (see Figures 2 and 3).

A variety of student engagement techniques were selected to use during class sessions. Techniques were selected based on an analysis of those that would best promote higher engagement and cognition (Finkel, 2000; Himmele \& Himmele, 2011; Yokomoto, \& Ware, 1997). See Appendix A for a description of these activities.

Surveys were administered at the end of each semester. The survey consisted of seven questions that students responded to on a 5-point Likert scale (1: always; 2: usually; 3: sometimes; 4: seldom; and 5: never) and three additional questions that were open-ended. These surveys included questions that focused on engagement in behavioral, cognitive, and affective domains. According to Fredericks, Blumenfeld, and Paris (2004), there are three types of classroombased engagement: behavioral, cognitive, and affective. Behavioral refers to 'ontask' behaviors. Cognitive engagement involves the ability to achieve higher-level understanding of materials focusing on Bloom's taxonomy levels of analysis, evaluation, and creativity. Affective engagement measures the student's attitude towards the subject matter as well as interest in the topic. These areas can be measured through teacher observations as well as student self-assessments.

\section{Results}

\section{Student Engagement Ratings}

The peer coaching process was used to inform one another about observed student engagement levels during class activities. This analysis was based on the use of Himmele and Himmele's (2011) TPT Cognitive Engagement Model and Quadrant Analysis. A research assistant also observed each class in order to control for bias. Observers (the peer coach and the research assistant) recorded the amount of instructional time that the teacher spent in each quadrant. The results indicate the total percentage of instructional time for each quadrant over four, ninety-minute class periods (see Figures $2 \& 3$ ).

\section{Cognition Engagement Model and Quadrant} Analysis Results for Class A

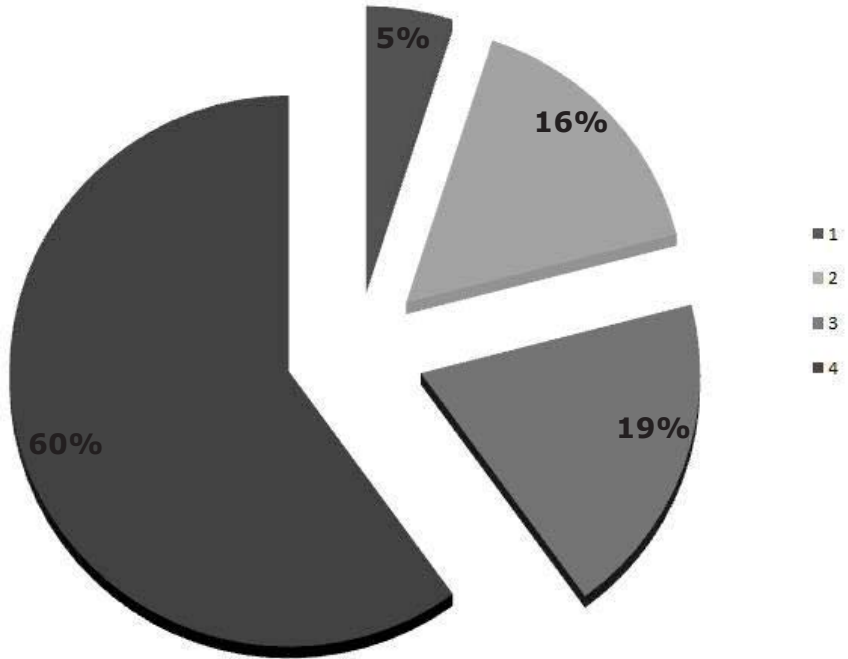

Figure 2. Quadrant Analysis Results for Class A 


\section{Cognitive Engagement Model and Quadrant Analysis Results for Class B}
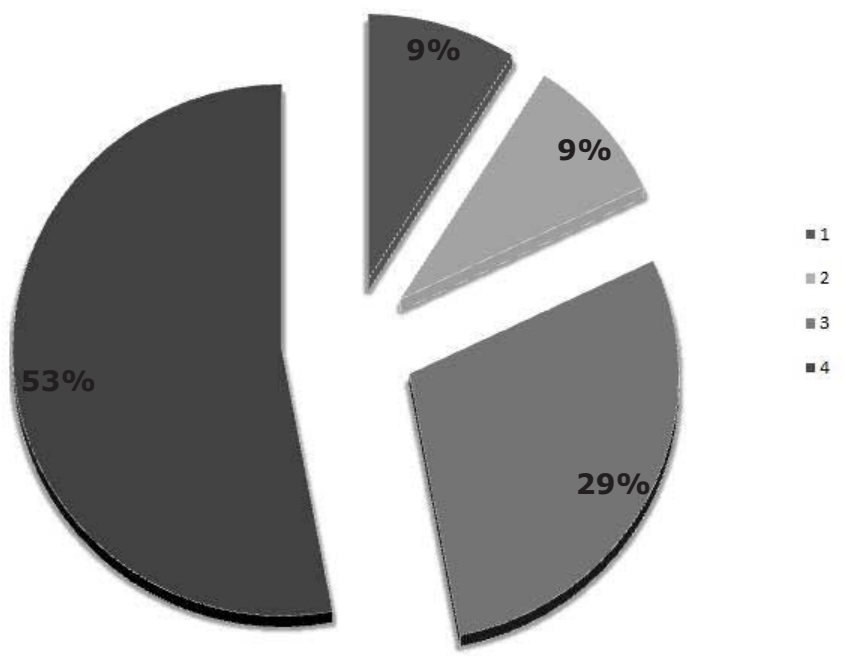

Figure 3. Quadrant Analysis Results for Class B

Class A analysis found that students were engaged in quadrants three and four for $75 \%$ of the time. Class B was engaged in quadrants three and four $82 \%$ of the time. Quadrant three focuses on high cognition and low participation. When class time was spent in this quadrant, activities were designed for high cognition, but not all students would be observed as actively participating. Quadrant four requires high cognition and also high participation. Class time was comprised of collaborative activities that required students to actively participate in pairs and/or small groups to apply what they had learned through discussion and in writing.

Analysis of classroom events indicated that quadrant three activities included group quizzes and similes. These activities received the rating of three because observers noted that not all students participated actively. During the group quiz activity, it was observed that a self-appointed leader would take over and dominate the group. Students who had not read the assignment upon which the quiz was based would assume the role of scribe and would then allow other students in the group to provide the needed answers.

Creating similes requires analytical thinking about a topic as students are asked to make comparisons between both terms. (e.g., 'A literacy coach is like a lighthouse'). Again, however, it was observed that some students would be more active during this activity while others assumed the role of an observer. Only when each individual was asked to independently create their own simile and then to share it with the class and explain its significance could quadrant four be achieved.

Quadrant four activities were identified as the Debate Team Carousel, Conceptual Workshop, Chalkboard Splash, and Three-Sentence Wrap-up. Debate Team Carousel and the Conceptual Workshop were both extremely successful in terms of achieving full participation and higher order thinking. In Debate Team Carousel, students were provided with a form (see Appendix B) that allowed them to work in a small group and individually respond to a specific prompt.

All students were actively engaged during this activity because they were individually responsible for a written response.

The prompt was one that required both judgmental and evaluative skills. Each student recorded both his/her opinion and the rationale for that opinion. Then papers were passed to the next person in the group who responded by providing a 
supporting and then an opposing opinion. All students were actively engaged during this activity because they were individually responsible for a written response. The discussion that followed was lively as students explained their rationales.

The Conceptual Workshop was similar in terms of requiring all students to provide written responses. See Appendix B for an example of a workshop developed to help students learn about dyslexia. In this format, students were provided a form with written questions that required initial research, synthesis, and evaluation. They were given ample time to find and discuss their response. Formerly, when dyslexia was initially taught, it was done so through teacher lecture and a PowerPoint. Testing results on the topic at the end of previous semesters were disappointing. It seemed that little was remembered. At the end of the semester in which the Conceptual Workshop was used, $95 \%$ of the students were able to answer questions on this topic correctly.

The Chalkboard Splash activity required students to respond individually to questions requiring the skills of analysis, synthesis, and evaluation. After the instructor posed a question, students would write their responses and then copy what they had written on the board. This activity resulted in spirited discussions as students read one another's responses and evaluated them for similarities, differences and surprises.

The Three-Sentence Wrap-up, although not a new concept, was found to be not only difficult for students, but also very informative for us as instructors. It is only easy to summarize what the key points of a lesson are when one truly understands that lesson. Trying to limit an explanation requires true analysis and synthesis of the material that was presented. This activity clearly showed us who understood and who was having difficulty with major concepts that were important in each classroom.

In conclusion, both professors had similar levels of engagement for both quadrants three and four. This, we believe, was due to the fact that extensive dialogue occurred on the topic of using activities that would contribute to participation on these levels. Using peer-coaching techniques was a useful way of analyzing engagement accurately. At times, we would tend to misread our own class, believing that all students were fully engaged and learning. The independent observer and peer coach would have hard evidence that this belief was not actually true. Written notes taken during observations would indicate whether or not all students were actually engaged in the task that had been presented.

\section{Student Surveys}

The analysis of the survey questions (see Table 1 ) indicated similar results for both classes. Responses of either a one or a two on the Likert scale were interpreted as being positive. Percentages reported denote the percent of students who responded positively to each question.

Table 1

Student Survey Results

\begin{tabular}{|l|c|c|c|}
\hline \multicolumn{1}{|c|}{ Question } & $\begin{array}{c}\text { Class } \\
\text { A }\end{array}$ & $\begin{array}{c}\text { Class } \\
\text { B }\end{array}$ & Engagement Type \\
\hline $\begin{array}{l}\text { 1. Collaborative grouping/activities } \\
\text { helped me to understand the content. }\end{array}$ & $84 \%$ & $80 \%$ & Cognitive \\
\hline $\begin{array}{l}\text { 2. Collaborative grouping/activities } \\
\text { made me want to participate more. }\end{array}$ & $74 \%$ & $60 \%$ & Affective \\
\hline 3. I took careful notes during class. & $74 \%$ & $60 \%$ & Behavioral \\
\hline $\begin{array}{l}\text { 4. I connected new learning to } \\
\text { information I already knew. }\end{array}$ & $95 \%$ & $90 \%$ & Cognitive \\
\hline
\end{tabular}




\begin{tabular}{|l|c|c|c|}
\hline $\begin{array}{l}\text { 5. I identified key information from } \\
\text { reading assignments. }\end{array}$ & $79 \%$ & $80 \%$ & Cognitive \\
\hline 6. I asked questions in class. & $63 \%$ & $70 \%$ & Behavioral \\
\hline 7. I contributed to class discussions. & $79 \%$ & $80 \%$ & Behavioral \\
\hline $\mathrm{N}=55$
\end{tabular}

\begin{tabular}{|c|c|c|c|}
\hline \multicolumn{4}{|l|}{ Open-Ended Questions } \\
\hline Question & Class A & Class B & $\begin{array}{c}\text { Engagement } \\
\text { Type }\end{array}$ \\
\hline $\begin{array}{l}\text { 8. Describe additional information } \\
\text { about how collaborative activities } \\
\text { helped or did not help your } \\
\text { learning. }\end{array}$ & $\begin{array}{c}84 \% \\
\text { Positive }\end{array}$ & $\begin{array}{c}70 \% \\
\text { Positive }\end{array}$ & Affective \\
\hline $\begin{array}{l}\text { 9. What do you think motivates } \\
\text { you to learn content materials } \\
\text { from class the most? }\end{array}$ & $\begin{array}{c}58 \% \\
\text { Internal } \\
42 \% \\
\text { Pedagogy }\end{array}$ & $\begin{array}{c}40 \% \\
\text { Internal } \\
60 \% \\
\text { Pedagogy }\end{array}$ & Affective \\
\hline $\begin{array}{l}\text { 10. What do you think gets in the } \\
\text { way of your true learning? }\end{array}$ & Life & Life & Affective \\
\hline \multicolumn{4}{|l|}{$N=55$} \\
\hline
\end{tabular}

The researchers categorized questions one, four, and five as those that measured cognitive levels of engagement. Eighty-four percent of the students in Class A responded positively to question 1 while Class B's responses were $80 \%$ indicating that students found that collaborative activities helped them to understand the content. For question four which asked if students connected new learning to previous learning, $95 \%$ of the students in Class A and $90 \%$ of the students in Class B responded positively. Question five asking if students identified key information from reading assignments was also responded to very similarly with $79 \%$ positive responses in Class $\mathrm{A}$ and $80 \%$ in Class $\mathrm{B}$.

Questions three, six, and seven were categorized as questions that measured behavioral levels of engagement. Question three asked if students took careful notes during class. In Class $A, 74 \%$ of the students responded positively while in Class B, only $60 \%$ responded positively. (This discrepancy was later found to be due to a difference in class requirements-Class A required students to take notes). Questions six and seven targeted class participation. Question six asked if students asked questions during class. Sixty-three percent responded positively in Class A while $70 \%$ responded positively in Class B. Question 7 asked if students contributed to class discussions and $79 \%$ and $80 \%$ of the students in Class A and B respectively responded positively.

For affective levels of engagement, Question two asked if collaborative grouping activities encouraged the student to participate more in class. Seventyfour percent of the students in Class $A$ responded positively, and $60 \%$ responded positively in Class B.

Three open-ended questions were also asked on the survey. The first question was - describe additional information about how collaborative activities helped or did not help your learning. Eighty-four percent of the answers in Class A were positive and $70 \%$ in Class B were positive. Typical positive and negative comments to this question can be seen in Table 2 . 
Table 2

Student Comments to Question 8

\begin{tabular}{|c|c|}
\hline Positive Comments & Negative Comments \\
\hline $\begin{array}{l}\text { - I benefited greatly from the } \\
\text { group work. I was able to } \\
\text { get others opinions and } \\
\text { clarification if I needed to } \\
\text { Working in small groups } \\
\text { helped me garner ideas, } \\
\text { share, and bounce ideas off } \\
\text { of one another } \\
\text { The collaborative activities } \\
\text { seemed to be more engaging } \\
\text { and we could bounce ideas } \\
\text { and thoughts off of each } \\
\text { other to come up with the } \\
\text { best answer. }\end{array}$ & $\begin{array}{l}\text { Collaborative activities did } \\
\text { not help because other } \\
\text { people answered the } \\
\text { questions for me } \\
\text { I often felt that group work } \\
\text { was just busy work - we had } \\
\text { already covered the material } \\
\text { so there was no need to do } \\
\text { group work too } \\
\text { It helps make it interesting, } \\
\text { but the same method over } \\
\text { and over can get boring. }\end{array}$ \\
\hline
\end{tabular}

The second question was - what do you think motivates you to learn content materials from class the most? Typical responses included statements such as:

- clear expectations - engaging class activities and instructor as a model for future teachers

- $\quad$ talking with others and reviewing the material through various class group activities

- $\quad$ the group collaborative work

Responses were then divided into two major categories-internal motivation and those that responded more to pedagogy. Some responses expressed a strong desire to learn and do well in the student's chosen career. Others felt more motivated by the instructor and the methods of instruction. In Class A, 58\% were categorized as being internally motivated and $42 \%$ were categorized as being motived by the teacher. In Class B, $40 \%$ were motivated intrinsically and sixty percent were motived by the teacher.

The last question was - what do you think gets in the way of your true learning? Most responses were framed around personal issues like time, home life, and too many classes. A few responses however, confirmed the need for collaborative activities and were usually stated as the need for more 'learning by doing' opportunities.

\section{Discussion}

Alison King (1993) first referred to the college professor as the "sage on the stage" (p.30)-the central figure who lectures while students take notes. Morrison (2014) notes that this role has changed as "the teacher has changed in a significant and positive way: no longer a 'sage on the stage', the teacher now functions as more of a 'guide on the side'" (p. 1). He points out, however, that this change also relies on a change in the students' role in terms of responsibility

It is their responsibility to learn as much as it is our responsibility to teach. and obligation to be active learners. When we first began this study we focused on the issue of improving our students and making them better learners. In the middle of the study we began to focus more on what we, as teachers, could do to improve our own instruction in order to motivate and engage our undergraduate students. 
By the conclusion of the study, we realized that it is a two-fold responsibility. As Morrison writes, part of the onus of this task rests on the students themselves. It is their responsibility to learn as much as it is our responsibility to teach.

Responses on question nine on our student survey relate somewhat to this issue. In class $\mathrm{A}$, a larger number of students expressed motivators to learning that dealt more with an internal drive to do well and be the best they could be as a teacher. This caused us to question why and to look for what might be the differences between the two classes. A deeper analysis revealed that there were more non-traditional, or older, students in Class A than there were in Class B. These older students seemed to exemplify what Morrison (2014) saw as a change in a student's role-the realization that it was their responsibility to learn. However, it is not always the non-traditional student with this type of intrinsic motivation. We have encountered many traditional students who demonstrate that internal drive to learn.

The TPT Cognitive Engagement Model and Quadrant Analysis procedure helped us to dramatically change our methods of teaching. Previously we had attempted activities that we thought would engage our students during class. We would show videos, ask questions, lecture with PowerPoint, and form small groups to participate in application activities related to assigned readings. Analysis of these activities made us realize that our activities were more in quadrants one and two than in three and four. Our former activities

The survey data demonstrated that a majority of students felt that the collaborative activities helped them understand the content better and motivated them to learn more about the content.

depended upon the ability to remember information, demonstrate comprehension, and apply learning in concrete situations. Total participation techniques and others found in the literature were incorporated into our teaching with more deliberation and true purpose in order to engage all students at higher-levels of cognition.

The survey data demonstrated that a majority of students felt that the collaborative activities helped them understand the content better and motivated them to learn more about the content. However, we have no solid evidence that students actually learned the material better. This leaves us with another question-what is the relationship between student engagement and academic achievement itself? National concerns have been raised by such recent publications as Academically Adrift (Arum \& Roksa, 2011), which presents issues concerning the lack of real learning in institutions of higher education. Further exploration in this area-the relationship between student engagement and academic achievement itself-would be warranted as an extension of this research.

\section{References}

AlKandari, N. (2012). Students' Arum, R., \& Roksa, J. (2011). communication and positive outcomes in Academically adrift: Limited learning college classrooms. Education, 133(1), 19- on college campuses. Chicago: 30. Retrieved from University of Chicago Press.

http://www.ingentaconnect.com/content/p rin/ed;jsessionid=bc9rma4v857d.alexandr a

Auman, C. (2011). Using simulation games to increase student and instructor engagement. College

Anderson, L. W., \& Krathwohl, D. R. (Eds.), Airasian, P. W., Cruikshank, K. A., Mayer, R. E., Pintrich, P.R., . . . Wittrock, M. C. (2001). A taxomony for learning, teaching, and assessing: $A$ revision of Bloom's taxonomy of educational objectives (Complete edition). New York, NY: Longman. 
Barkley, E. F. (2010). Student engagement techniques: $A$ handbook for college faculty. San Francisco, CA: Jossey-Bass.

Beran, T., \& Violato, C. (2009). Student ratings of teaching effectiveness: Student engagement and course characteristics. Canadian Journal of Higher Education, 39(4), 296-306. Retrieved from

http://ojs.library.ubc.ca/index.php/cjhe

Bloom, B. S., Englehart, M. D., Furst, E. J., Hill, W. H., \& Krathwohl, R. R. (Eds.). (1956). Taxonomy of educational objectives: The classification of educational goals (Vol 1.Cognitive domain). New York, NY: David McKay.

Chiu, Y. J. (2009). Facilitating Asian students' critical thinking in online discussions. British Journal of Educational Technology, 40(1), 42-75. doi:10.1111/j.1467-8535.2008.00898.x

David, M. (2004). What does it mean to participate in class?: Integrity and inconsistency in classroom interaction. Journal of Classroom Interaction, 39(1), 19-29. Retrieved from http://www.jciuh.org/

Finkel, D. L. (2000). Teaching with your mouth shut. Portsmouth, $\mathrm{NH}$ : Heinemann.

Freeman. M., Anderman, L. H., \& Jensen, J. M. (2007). Sense of belonging in college freshmen at the classroom and campus levels. The Journal of Experimental Education, 75(3), 203220. doi: $10.3200 / J E X E .75 .3 .203-220$

Fredericks, J. A., Blumenfeld, P. C., \& Paris, A. H. (2004). School engagement: Potential of the concept, state of evidence. Review of Educational Research, 74(1), 59-109. doi: 10.3102/00346543074001059

Freire, P. (2000). Pedagogy of the oppressed. ( $30^{\text {th }}$ anniversary edition). New York: Continuum International Publishing Group. (Original work published 1970).
Goldberg, N., \& Ingram, K. (2011). Improving student engagement in a lower-division botany course. Journal of the Scholarship of Teaching and Learning, 11(2), 76-90. Retrieved from http://josotl.indiana.edu/

Himmele, P., \& Himmele, W. (2011). Total participation techniques. Alexandria, VA: Association for Supervision and Curriculum Development-ASCD.

King, A. (1993). From sage on the stage to guide on the side. College Teaching, 41(1). 30-35. Retrieved from http://www.tandfonline.com/loi/vcol20

Morrison, C. D. (2014). From 'sage on the stage' to 'guide on the side': A good start. International Journal for the Scholarship of Teaching and Learning, $8(1)$, Article 4. Retrieved from http://digitalcommons.georgiasouthern. edu/ijsotl/vol8/iss1/4

Pellicer, L., \& Anderson, L. (1995). A handbook for teacher leaders. Thousand Oaks, CA: Corwin Press.

Petress, K. (2006). An operational definition of class participation. College Student Journal, 40(4), 821-823. Retrieved from http://www.projectinnovation.com/colle ge-student- journal.html

Rocca, K. A. (2008/2009). Participation in the college classroom: The impact of instruct immediacy and verbal aggression. Journal of Classroom Interaction, 43(2), 22-33. Retrieved from http://www.jciuh.org/

Weiman, C., \& Perkins, K. (2005). Transforming physics education. Physics Today, 58(11), 36-49. Retrieved from http://scitation.aip.org/content/aip/mag azine/physicstoday/issues; jsessionid $=4 \mathrm{c}$ wco90fbge16.x-aip-live-02 
Yokomoto, C. F., \& Ware, R. (1997).

Variations of the group quiz that promote collaborative learning.

Proceedings of the Frontiers in Education

Conference, 1, 552-557. doi:

10.1109/FIE.1997.644946

Appendix A

Classroom Activities Used During the Study

\begin{tabular}{|l|l|}
\hline Classroom Activity: & Description: \\
\hline $\begin{array}{l}\text { Debate Team Carousel (Himmele \& } \\
\text { Himmele, 2011) }\end{array}$ & $\begin{array}{l}\text { Students debate an issue in small } \\
\text { groups, offering opposing viewpoints } \\
\text { and validating with support from class } \\
\text { texts/discussions. }\end{array}$ \\
\hline $\begin{array}{l}\text { Group Quizzes (Yokomoto, C. F. \& } \\
\text { Ware, R., 1997) }\end{array}$ & $\begin{array}{l}\text { Students form small groups and } \\
\text { respond to 2-3 quiz questions from } \\
\text { classroom readings. They present their } \\
\text { answers to the whole class and are } \\
\text { allowed to debate responses. }\end{array}$ \\
\hline $\begin{array}{l}\text { Chalkboard Splash (Himmele \& } \\
\text { Himmele, 2011) }\end{array}$ & $\begin{array}{l}\text { All students record their responses to a } \\
\text { key question on a large board of poster } \\
\text { and then analyze peer responses for } \\
\text { similarities, differences, and surprises. }\end{array}$ \\
\hline $\begin{array}{l}\text { Three-Sentence Wrap-Up } \\
\text { (Himmele \& Himmele, 2011) }\end{array}$ & $\begin{array}{l}\text { Students work collaboratively in small } \\
\text { groups to answer a set of questions } \\
\text { that all lead to an understanding of the } \\
\text { central concepts. }\end{array}$ \\
\hline Similes (Himmele \& Himmele, 2011) & $\begin{array}{l}\text { Students summarize what was learned } \\
\text { in 3 sentences or less. }\end{array}$ \\
\hline & $\begin{array}{l}\text { Students compare two unrelated things } \\
\text { in order to demonstrate abstract } \\
\text { thinking about key concepts in a way } \\
\text { that sums up meaning. }\end{array}$ \\
\hline
\end{tabular}


Appendix B

Description of 2 Quadrant Four Activities

Debate Team Carousel (Himmele \& Himmele, 2011, p. 95)

\section{Give your opinion and explain your rationale.}

Record your opinion and explain your reason for it.

\section{Add an opposing argument.}

In this box, record a reason that might be used to argue against what is written in boxes \# 1 and \#2.

\section{Add a support argument.}

Read your classmate's response. In this box, add another reason that would support your classmate's response.

\section{Add your "two cents."}

Read what is written in the three boxes. Add your opinion and your reason for it in this box.

\section{Conceptual Workshop (Finkel, 2000)}

\section{Conceptual Workshop: Dyslexia}

Part I (20 minutes): Divide into groups of 4 and select one person ahead of time to record the answers on another sheet of paper. Select another person to keep track of time to make sure the group answers all questions in the allotted time. Each person in your group must participate in developing the answers to the questions below. You may use the PowerPoint or articles provided or other sources of legitimate information.

1. List the key elements that are used to define dyslexia. Put these into your own words-don't just copy the phrases from the text. Then write a definition that you could use to explain dyslexia to parents or other non-educators.

2. Based on what you read, explain what is meant by "the phonological component of language". Again, use your own words. List the key facts that educators should understand about this area.

3. Describe how you would identify this learning problem as a classroom teacher.

Part II (30 minutes): Think about what you discussed with the questions above, about the information in the PowerPoint, and the information in Cunningham's book Phonics They Use. What type of remediation program could you develop to help a student with dyslexia? 
Paula Witkowski, PhD, is an associate professor within the School of Education at Webster University in St. Louis, Missouri. She teaches reading methods classes and graduate literacy courses in the Communication Arts, Reading, and Early Childhood Department. She has thirty years of experience in K-12 schools as a speechlanguage pathologist and reading specialist. Her research interests include language development, emergent literacy, elementary and adolescent reading instruction, and comprehension strategies.

Thomas Cornell, EdD, is an associate professor within the School of Education at Webster University in St. Louis, Missouri. He teaches reading methods classes and graduate literacy courses in the Communication Arts, Reading, and Early Childhood Department. He has thirty years of experience in $\mathrm{K}-12$ schools as a classroom teacher, reading specialist, Title 1 Coordinator, and Communication Arts Coordinator. His research interests include content reading, literacy coaching, and elementary reading instruction. 